\title{
Evaluating the effect of grain size and salts on liquid water content in frozen soils of Antarctica by combining NMR, chemical equilibrium modeling, and scattered diffraction analysis
}

\author{
Liliya Vugmeyster ${ }^{\mathrm{a}, *}$, Birgit Hagedorn ${ }^{\mathrm{b}}$, Matthew A. Clark ${ }^{\mathrm{b}}$, R.S. Sletten ${ }^{\mathrm{c}}$ \\ a University of Colorado at Denver, Denver, CO 80204, United States \\ b University of Alaska Anchorage, Anchorage, AK 99508, United States \\ c University of Washington, Seattle, 98195, United States
}

\section{A R T I C L E I N F O}

\section{Article history:}

Received 15 September 2016

Accepted 27 March 2017

Available online $\mathrm{xxxx}$

\section{Keywords:}

Water content

NMR

FREZCHEM

Freezing curves

Antarctic soils

Grain size

Modeling

\begin{abstract}
A B S T R A C T
Recent studies point to the possible existence of liquid water on Mars surface. While many efforts have focused on experimental determination and modeling of liquid water content in inorganic-salt rich soils, additional factors that govern liquid water formation remain largely unexplored. The purpose of this study is to determine main soil properties that will affect unfrozen water content. We analyzed liquid water content and bulk freezing points using high field deuterium NMR measurements and compared the results to the amount of liquid water content at the same temperatures based on salt concentration and composition using an empirical chemical equilibrium model (FREZCHEM). We selected soils with a wide range of salt concentrations and composition collected from the McMurdo Dry Valleys, Antarctica. The comparison indicates that at 50\% unfrozen water content the freezing temperatures deviate substantially from water content modeled based on salt composition. In particular, the NMR freezing points are lower than those calculated with FREZCHEM for all low to medium salt content samples. The results indicate that soil properties other than aqueous chemical composition add to liquid water content. Particle size does not necessarily correlate with the liquid water content, revealing that more detailed investigation including surface area and composition may be necessary to describe the dependence of unfrozen water content on soil properties. The study highlights the necessity of experimental measurements of water content due to effects of multiple factors that are difficult to take into account in simulations.
\end{abstract}

(c) 2017 Elsevier B.V. All rights reserved.

\section{Introduction}

Studies indicate that transient liquid water may exist on Mars surface due to high salt concentrations and may support life (Boxe et al., 2012; Chevrier et al., 2009a; Cull et al., 2010; Davila et al., 2010; Hanley et al., 2012; Hecht et al., 2009; Marion et al., 2010; Rennó et al., 2009; Zorzano et al., 2009). In addition, deliquescence of iron sulfates and perchlorates may contribute to viscous flow and modern formation of Martian gullies (Chevrier et al., 2009b) Cull et al. (2010) interpret the occurrence of massive perchlorate as a result of salt transport through thin water films during seasonal ice covers. It is speculated that oscillation of temperatures above and below eutectic temperature may lead to the formation of excess pore ice over longer time periods (Rennó et al., 2009).

Another mechanism for liquid water survival in dry and cold environments is formation of adsorbed films on particle surfaces. It is

\footnotetext{
* Corresponding author.

E-mail address: LILIYA.VUGMEYSTER@UCDENVER.EDU (L. Vugmeyster).
}

believed that adsorbed water was observed by the Observatoire pour la Mineralogie l'Eau, les Glaces et l'Activite (OMEGA), indicating that at the Phoenix lander site $10-11 \%$ of water is likely adsorbed to particle surfaces (Poulet et al., 2010). In soils the adsorbed water is directly related to the relative humidity in the presence of ice and salt. Models designed for high ionic strength must be used to model the phases and unfrozen water content in such a multi-component system. In addition, the influence of interfaces on unfrozen water (Gibbs-Thomson effect) must be accounted for (Anderson and Morgenstern, 1973; Dash et al., 1995; Horiguchi, 1987; Rempel, 2011). The latter can have a dynamic (entropic) component stemming from motions of water molecules at the water-soil interface (Anderson and Anderson, 2010) (Rempel et al., 2004). Interfacial water is known to be important in many surface processes including: stability of suspensions (Crocker et al., 1999; Israelachvili and Wennerstrom, 1996), protein folding and dynamics (Bergknut et al., 2011; Frauenfelder et al., 2009; Graziano, 2010; Krushelnitsky et al., 2009; Mallamace et al., 2007; Sterpone et al., 2012; Vugmeyster et al., 2011), and clay swelling (Asay and Kim, 2005; Geissbuhler et al., 2004; Goertz et al., 2007; Karaborni et al., 
1996; Skelton et al., 2011). A recent study by Boxe et al. (2012) suggests that it is particularly important to study the films of liquid water on the surfaces of ice and their potential for supporting life. The role of interfacial interactions in the presence of water in soils at sub-zero temperatures remains largely unexplored. This interstitial/interfacial water may contribute to the formation and sustainability of subsurface ice and ground flow patterns. Interfacial water has been suggested as a potential habitat on Mars (Davila et al., 2010) and may facilitate the transport and concentration of salts to the subsurface. The determination of interstitial or bulk liquid water in soils at subzero temperatures is mostly based on modeling, empirical formulas (Anderson and Morgenstern, 1973; Anderson et al., 1973) or estimates based on salt concentrations.

The McMurdo Dry Valleys (MDV) comprise a series of valleys located between the East Antarctica Ice Sheet and Ross Sea, occupying elevations from sea level to $2 \mathrm{~km}$ (Fig. 1). The main lithology of these Valleys is comprised of basalt, sandstone, and granitoids, which form the major parent material for soils on the Valley floors (Bockheim, 2002; Campbell and Claridge, 1987; Ugolini and Bockheim, 2008). Soils at higher elevation valleys are virtually free of organic compounds and are rich in salts such as chloride, nitrate, and sulfate (Keys and Williams, 1981); minor compounds such as perchlorate have been discovered as well (Kounaves et al., 2010). Weathering is often indicated by red staining (rubification) due to oxidation of iron rich minerals such as olivine, pyroxene, amphibole, and biotite. Weathering stage correlates well with dithionite extractable iron (Claridge and Campbell, 1984). The majority of salts in Antarctic soils are atmospherically derived (Bao and Marchant, 2006; Campbell and Claridge, 1987; Keys and Williams, 1981 ) and modified by in situ weathering (Faure and Felder, 1981; Jones and Faure, 1978; Ugolini, 1986) including cation exchange (Toner and Sletten, 2013; Toner et al., 2013). Although salts are deposited on top of the surface initially, they display a compositional gradient downwards that is characterized by salt solubility that implies transport by aquatic saline solutions (brine) (Dickinson and Rosen, 2003;
Hagedorn et al., 2010). Occurrence of deliquescence at low and high elevations (Levy et al., 2012; Wilson, 1979) highlights the similarity of hydrological processes to Mars. Stable isotope profiles $\left(\delta D, \delta^{18} \mathrm{O}\right)$ in ground ice give evidence of infiltration of brine into frozen ground (Hagedorn et al., 2010) and thus point to the occurrence of brine transport at subzero temperatures. These transport mechanisms have also been implied for salt transport in Martian soils (Cull et al., 2010). Study by Toner and Sletten (2013) further indicate that cation exchange processes in brine films may lead to high concentrations of calcium chloride in Dry Valley soils and may lead to the development of $\mathrm{CaCl}_{2}-$ saturated Don Juan Pond.

This paper advances the study of liquid water molecular dynamics and content in conjunction with elevated salt concentrations. NMR experiments are employed to determine the liquid water content at subfreezing temperatures in soils collected from McMurdo Dry Valleys, Antarctica in 2008 and 2010. We compare NMR-determined water content to prediction based on thermodynamic chemical equilibria using the program FREZCHEM (Marion and Grant, 1994). Our results indicate a difference in liquid water content at given temperatures between both approaches, thus demonstrating that unfrozen water content is affected by multiple factors that are difficult to account for using only chemical modeling.

\section{Samples and methods}

\subsection{Soil samples and preparation}

Soil samples were collected during two expeditions lead by $\mathrm{R}$. Sletten, University of Washington, to MDV in 2008 and 2010 from Beacon Valley, its side valleys Mullin and Farnell, and Mount Fleming (Fig. 1). The selection of soil samples and sites was based on the goal to sample a large variation in salt concentration and composition. Samples were dried at $50{ }^{\circ} \mathrm{C}$ (which is a typical drying temperature when

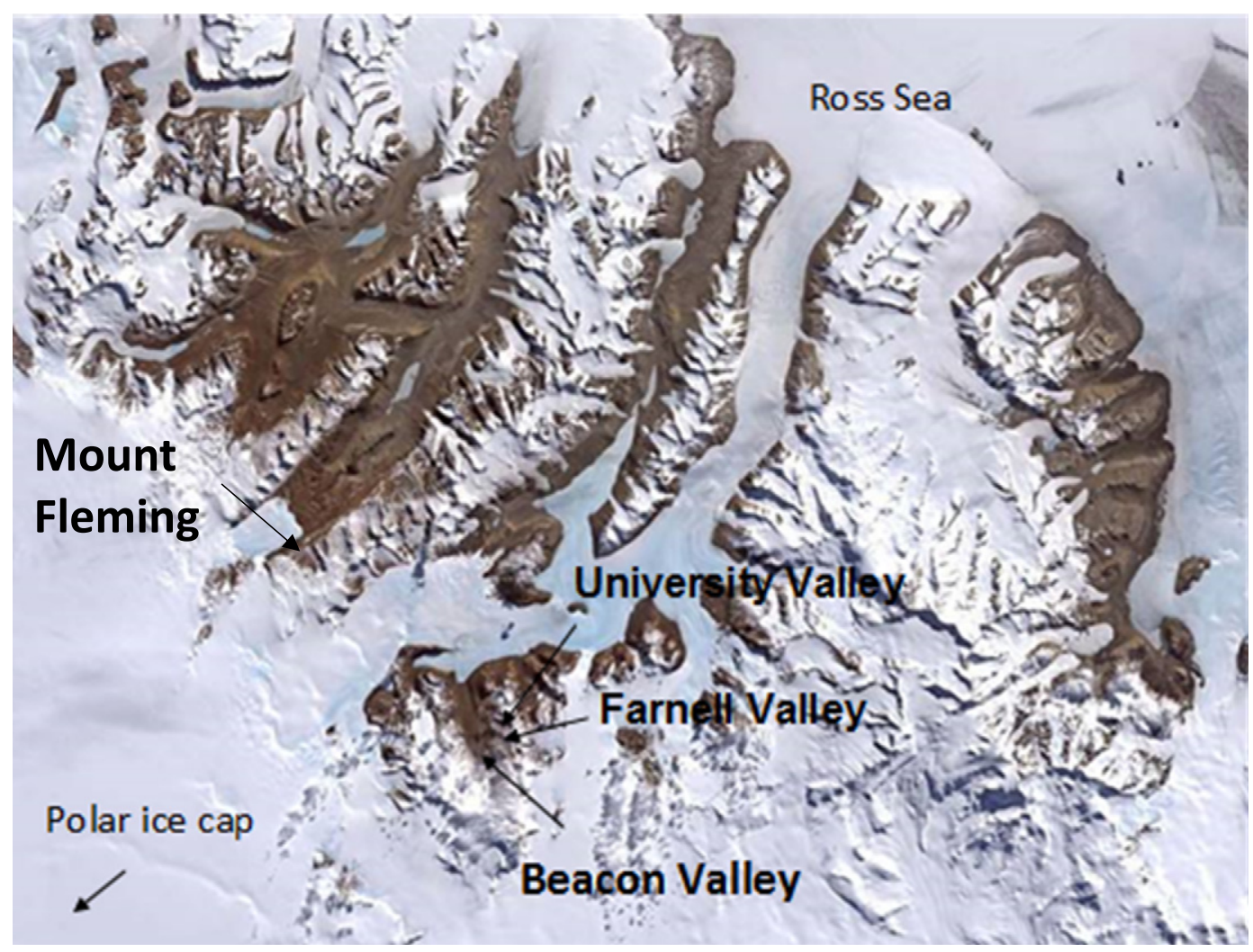

Fig. 1. Location of Beacon Valley, its side valleys and soil sample collection points. 
Table 1

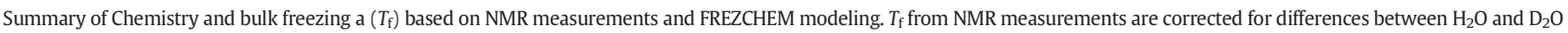
freezing points. Precision of NMR freezing points is $0.5^{\circ}$. For samples 8-18-4 and 8-22-3 FREZCHEM-based $T_{\mathrm{f}}$ values represent their upper boundaries.

\begin{tabular}{|c|c|c|c|c|c|c|c|c|c|c|c|}
\hline Sample & $\mathrm{Ca}$ & $\mathrm{Cl}$ & K & $\mathrm{Mg}$ & $\mathrm{NO}_{3}$ & $\mathrm{Na}$ & $\mathrm{SO}_{4}$ & total & Grain size & $T_{\mathrm{f}}(\mathrm{K})$ & \\
\hline & $\mathrm{mmol} / \mathrm{kg}$ & & & & & & & & $\mu \mathrm{m}$ & NMR & FREZ \\
\hline $8-26-3$ & 157 & 48 & 15 & 82 & 2251 & 1995 & 95 & 4643 & 754 & 257 & 266 \\
\hline $8-26-6$ & 13 & 50 & 21 & 18 & 35 & 60 & 26 & 223 & 625 & 265 & 272 \\
\hline 8-64-1 & 1832 & 115 & 8 & 107 & 128 & 122 & 1882 & 4194 & 888 & 266 & 272 \\
\hline $8-64-3$ & 184 & 75 & 5.1 & 46 & 51 & 104 & 222 & 687 & 576 & 266 & 272 \\
\hline $8-14-2$ & 29 & 67 & 11 & 54 & 122 & 111 & 50 & 444 & 573 & 265 & 272 \\
\hline $8-14-4$ & 62 & 28 & 7.7 & 27 & 31 & 69 & 98 & 323 & 559 & 265 & 272 \\
\hline $8-18-2$ & 3260 & 301 & 23 & 191 & 286 & 335 & 3337 & 7733 & 208 & 265 & 267 \\
\hline $8-18-4$ & 13,290 & 689 & 51 & 463 & 855 & 973 & 13,490 & 17,850 & 5 & 264 & $<240$ \\
\hline $8-22-3^{a}$ & 511 & 16 & 159 & 6701 & 3676 & 4850 & 1170 & 17,083 & 124 & 252 & $<240$ \\
\hline
\end{tabular}

a FREZCHEM-based freezing point for sample 8-22-3 would only converge with an additional 50\% water content by weight.

mineralogy of secondary products such as salts or clay minerals, are of interest) and sieved at $2 \mathrm{~mm}$ for analysis. Samples with variable salt concentration were selected for the experiments (Table 1) based on their ionic concentration (see below). About 0.2-0.4 g of the selected samples were hydrated to $20 \%$ by weight with $\mathrm{D}_{2} \mathrm{O}$ enriched water. We assume that $20 \%(\mathrm{v} / \mathrm{w})$ is an average amount of water equivalent present in ice-cemented soils of MDV (Bockheim, 2002). After hydration, all samples were equilibrated for at least $48 \mathrm{~h}$ at room temperature, followed by at least a week in a refrigerator at $4{ }^{\circ} \mathrm{C}$.(Vugmeyster et al., 2012). This procedure allows equilibration of deuterated water throughout the entire sample.

\subsection{NMR spectroscopy}

NMR methodology allows for rapid determination of water content on undisturbed samples. Proton NMR is a relatively common technique in determining liquid water content (Watanabe and Wake, 2009). Deuterium NMR is much less commonly used yet offers the advantage of a better precision. We have employed a modified method previously developed by Sparrman et al. (2004) and determined liquid water content for a range of samples from different locations in the McMurdo Antarctic Dry Valleys at different depth levels (see Supplementary material). The technique relies on measuring magnetization of deuterium nuclei using the quadrupolar echo experiment (Vold and Vold, 1991; Vugmeyster et al., 2012). The only signal which is observed in this experiment is the one originating from liquid water, which can be quantified from the initial intensity of the free induction decay curve. Previous studies typically used $4 \% \mathrm{D}_{2} \mathrm{O}$; however, incorporation of $100 \% \mathrm{D}_{2} \mathrm{O}$ greatly enhances signal intensity and allows for more precise determination of liquid water content. We have confirmed that the incorporation of $100 \%$ $\mathrm{D}_{2} \mathrm{O}$ into the soil samples does not alter the freezing points beyond the differences between the freezing point of pure $\mathrm{H}_{2} \mathrm{O}\left(0^{\circ} \mathrm{C}\right)$ and $\mathrm{D}_{2} \mathrm{O}$ $\left(3.6^{\circ} \mathrm{C}\right)$. All of the reported NMR data on freezing curves and freezing points are shifted by a constant offset of $3.6{ }^{\circ} \mathrm{C}$ in order to show the results for non-deuterated water. Experimental details of the NMR procedure are available in the Supplementary material.

We demonstrated previously that hysteresis of water content in the cooling/heating curves using one of the representative samples (Vugmeyster et al., 2012). The hysteresis was confirmed for all of the samples probed in this study. Since the hysteresis behavior is not the focus of this work, we choose to concentrate on the cooling curves only, for which 30 min equilibration time was used between temperature points. Based on numerous temperature-dependent NMR studies, 30 min provide generous equilibration time inside the NMR tube and account for ice-formation kinetics(Beckmann and Dybowski, 2000; Sparrman et al., 2004; Vugmeyster et al., 2012; Vugmeyster et al., 2009).

\subsection{Impedance measurements}

As the salt-containing water freezes, an abrupt change in conductivity is expected. The Q-factor measurements (Tooley, 2002) (Jiang, 2000) with the sample inserted into the NMR probe is a specific approach for measuring conductivity/impedance. This approach permits for precise matching of conditions to those at which NMR measurement are performed. The $\mathrm{Q}$-factor $\left(Q_{S}\right)$ of the system was measured using an electrical network analyzer (i.e., a device that measures parameters of electrical networks) connected to the NMR probe. The measurements were taken at desired specific temperatures right before the NMR experiments. Thus, the conditions of the samples were identical for the NMR and $Q_{S}$ measurements. Reference values $Q_{r e f}$ were recorded for each temperature by using an empty tube. The reported quantity is given by $Q=1-Q_{S} / Q_{\text {ref }}$ and corrects for temperature-dependent changes in the NMR circuit that are not related to the sample. Freezing of bulk solvent in a lossy sample causes abrupt increase in the values of $Q_{S}$, making it a convenient, robust measure of bulk solvent freezing points.

\subsection{Chemical analysis}

About $2 \mathrm{~mL}$ of each sample was extracted with purified water in a 1:10 dilution and analyzed by Inductively Coupled Plasma Mass Spectrometry (ICP MS, Agilent 7500c) and Ion Chromatography (IC. Dionex IC 500) for initial screening of salt content and composition. After the NMR measurements, ICPMS and IC samples were taken directly from the NMR tube and, based on previous measurements, were diluted to fit calibration of the instruments (ICP MS: 0.01 to $10 \mathrm{ppm}$,; IC: 0.1 to $10 \mathrm{ppm}$ ). Samples were filtered through $0.2 \mu \mathrm{m}$ syringe filters and acidified to $1 \%$ HNO3 (v/v) for metal analysis following EPA 200.8 method. The international standard SRM 1640 was used for calibration verification. For anion analysis, samples were pipetted into $2 \mathrm{~mL}$ glass vials and analyzed with an AS15 column using $\mathrm{KOH}$ as eluent and a selfregenerating suppressor.

\subsection{Grain size measurements}

The grain size analysis was performed on $\sim 1 \mathrm{~g}$ sample aliquot using a laser diffraction particle size analyzer (Beckman Coulter LS 13-320). Samples were dispersed by an ultrasonic probe in sodium hexametaphosphate/carbonate added to avoid agglomeration and to keep the sample in suspension during analysis. Between 2 and 7 measurements were performed for each sample to assure reproducibility.

\subsection{FREZCHEM modeling}

The FREZCHEM72 model is an equilibrium model that uses Pitzer model of ion interactions at high concentration (Marion and Grant, 1994) (Marion and Kargel, 2008) and is designed to track the amount of liquid water and salt precipitation during evaporation or freezing (Marion, 1999; Marion, 2001, 2002). The model assumes that equilibration occurs between the salts and solution. We chose the equilibration between solids and liquid assuming that salts and ice will be in constant contact with liquid water. FREZCHEM requires a perfect charge balance 
and to achieve this we calculated the salt concentrations from the ICP MS and IC results assuming 20\% water content in soils, and then modeled these with PHREEQC version 3 (Parkhurst and Appelo, 1999) (http://wwwbrr.cr.usgs.gov/projects/GWC_coupled/phreeqc/) and adjusted the concentration of $\mathrm{SO}_{4}^{2-}$ slightly to achieve the charge balance. The output concentrations from PHREEQC in units of $\mathrm{mol} \cdot \mathrm{kg}^{-1}$ was then used in the FREZCHEM model; all primary data are listed in the Supplementary material. Freezing was done in 5-degree increments from $+5{ }^{\circ} \mathrm{C}$ to $-25{ }^{\circ} \mathrm{C}$. The $5^{\circ}$ intervals are sufficient to trace out the temperature-dependence. Samples with very high salt concentrations did not converge at low temperatures, as indicated in Table 1.

\section{Results and discussions}

\subsection{Experimental determination of liquid water content}

The results of our analyses are summarized in Figs. 2 and 3, as well as in Table 1. The analyzed samples had different salt concentrations and compositions as documented in Table 1. Some soil samples were from the same soil pit, but collected at different depths, with higher salt concentrations in the upper soil profile and lower concentration lower in the profile (e.g. 8-26-3 top, 8-26-6 bottom). The freezing temperature $T_{\mathrm{f}}$ was defined as the temperature at which the liquid water content is half of its maximum value. The NMR data (Fig. 2) corresponding to low and medium salt content samples show clear pre and post- transition regions. The pre/post transition regions refer to the relatively leveled regions of the sigmoidal freezing curves. For the high salt content samples shown in Fig. 3 (samples 8-18-4, 8-22-3, and 18-8-2) these regions are less defined.

To supplement NMR measurement, we conducted the impedance (conductivity) measurements on the same samples to check for correspondence between the two techniques. Abrupt conductivity changes due to freezing of bulk solvent in a salt-containing sample are relatively easy to detect and provide a good baseline control for more sophisticated techniques geared toward quantification of remaining liquid water content. As shown in the example below (Fig. 4), the freezing points determined by the two approaches are in good agreement. This is important in light of recent results by Buehler et al. that utilized impedance spectroscopy to analyze water content in simulated Martian soils (Buehler et al., 2007; Seshadri et al., 2008). We also note that similar freezing curves have been reported by Tice and coworkers for saline silt of Lanzhou, China and low-salt silts from Alaska (Tice, 1984). In their work, electrical conductivity was also used as an independent measure of soluble salt content.

\subsection{Comparison with FREZCHEM modeling and grain size measurements}

FREZCHEM simulations use chemical equilibrium to obtain the activity of liquid water and predict freezing points based on salt composition of the sample (Table 1). During freeze-back, FREZCHEM calculates the
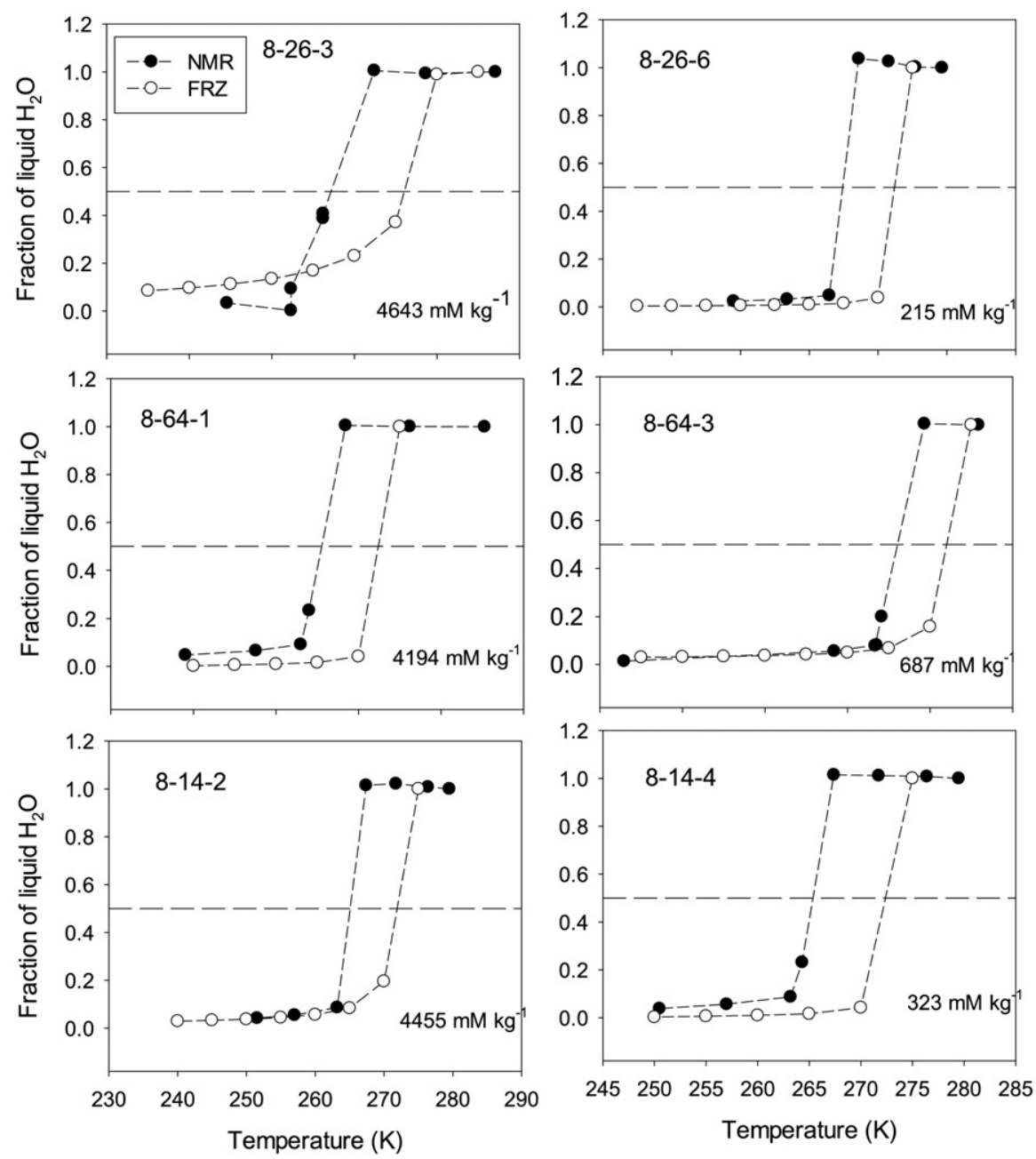

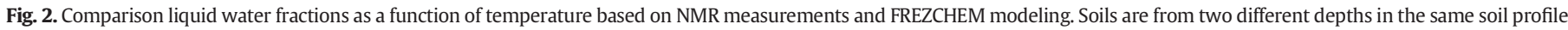

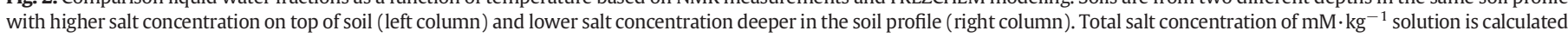
based on $20 \mathrm{wt} \%$ water content in soil. 

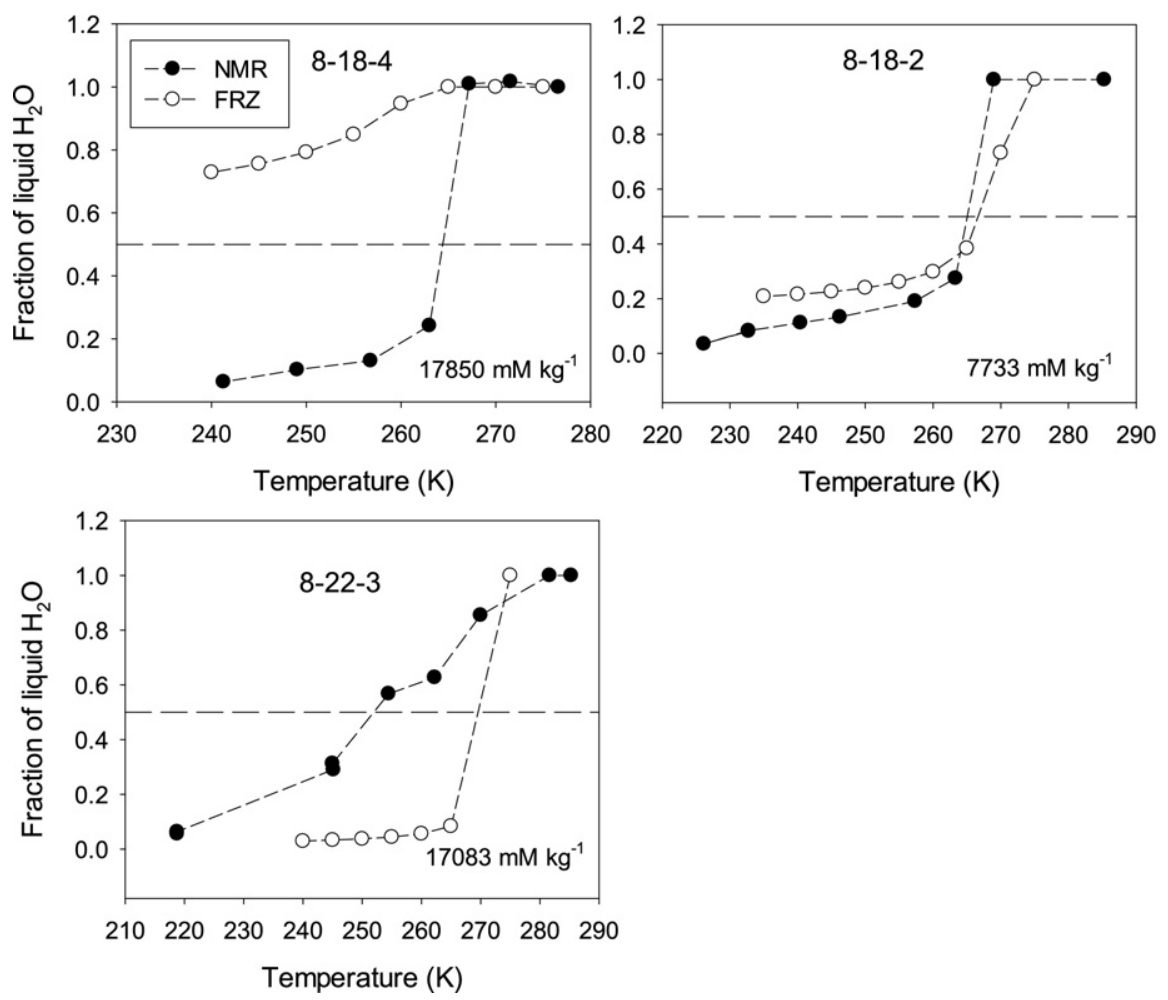

Fig. 3. Comparison of fraction of liquid water as a function of temperature between NMR measurement and FREZCHEM modeling for soil samples with very high salt concentration.

precipitation of salts. Based on the different chemical compositions, different salts are precipitated for each sample and chemical composition of the remaining solution changes throughout the process. Discrepancies in measured freezing points obtained by NMR method versus modeled freezing points by FREZCHEM are shown in Fig. 5. Additionally, there are discrepancies in the shape of the freezing curves (Figs. 2 and 3). The experimentally measured NMR freezing points are lower
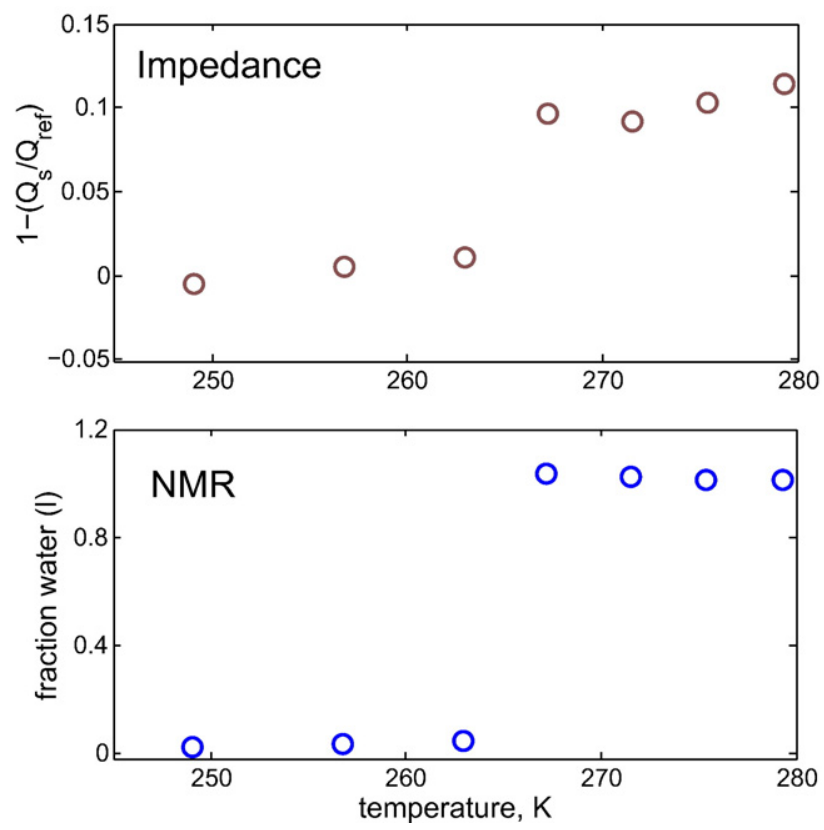

Fig. 4. Comparison of freezing points determination using impedance and NMR measurements for a sample from Beacon Valley (8-26-6 sample), demonstrating agreement between bulk freezing point determined by these two techniques. than those calculated with FREZCHEM for all samples with low to medium salt content. Two of the three samples with higher salt content have NMR bulk freezing points higher by $10-15^{\circ}$ compared to those predicted by FREZCHEM (8-18-4 and 8-22-3), and only for one sample (18-82 ) the bulk freezing points are in agreement. However, the actual freezing curve for the sample 8-18-2 is still somewhat different between NMR and FREZCHEM. Discrepancies in the liquid water content at subfreezing temperatures modeled with FREZCHEM and analyzed by NMR are not as pronounced when the fraction of liquid water is smaller than about $10 \%$, at temperature less than $-15{ }^{\circ} \mathrm{C}$. These temperatures are sustained at deeper soil horizons (e.g. Hagedorn et al., 2007), thus suggesting that modeling of freezing processes based solely on chemical equilibrium may miss certain soil properties, as well as water and solute kinetics. For example, the chemical equilibrium modeling suggests that the formation of salts such as Gypsum $\left(\mathrm{CaSO}_{4} \cdot 2 \mathrm{H}_{2} \mathrm{O}\right)$, Mirabillite

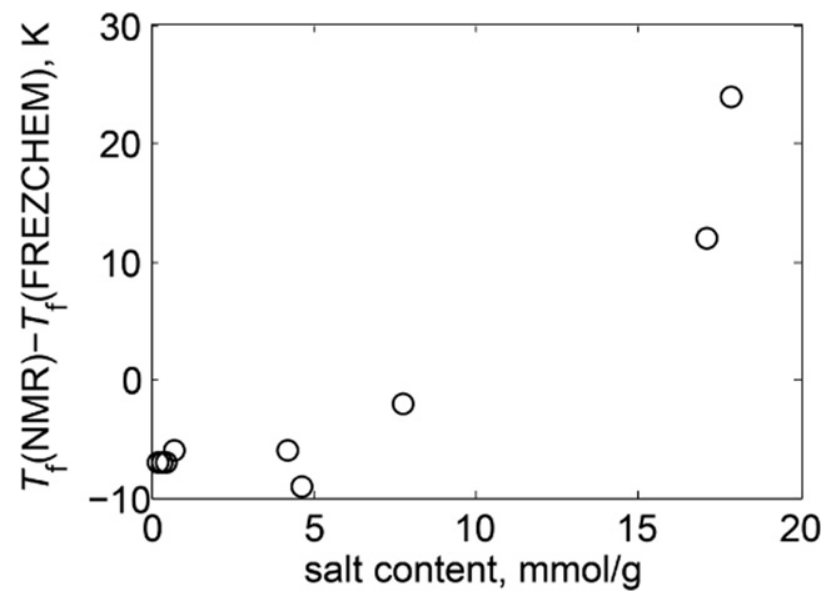

Fig. 5. Difference in $T_{\mathrm{f}}$ from NMR and FREZCHEM versus total salt concentration. $T_{\mathrm{f}}$ from NMR are corrected for differences between $\mathrm{H}_{2} \mathrm{O}$ and $\mathrm{D}_{2} \mathrm{O}$ freezing points. 


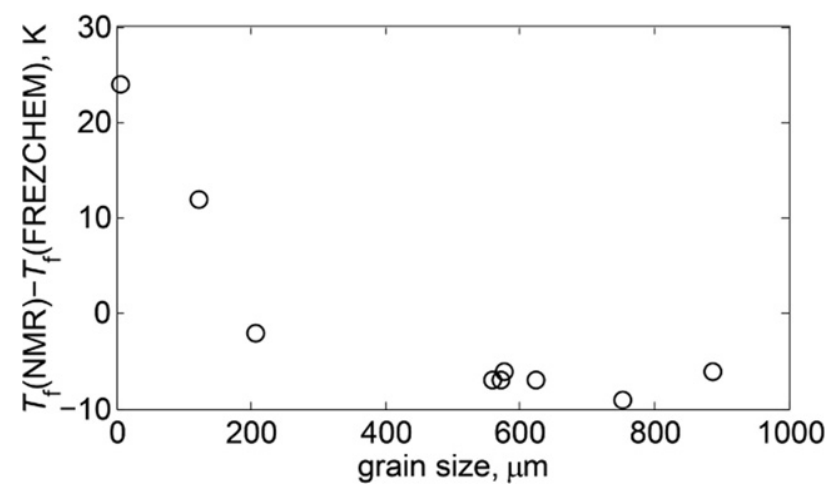

Fig. 6. Difference in $T_{\mathrm{f}}$ from NMR and FREZCHEM (50\%) versus grain size.

$\left(\mathrm{Na}_{2} \mathrm{SO}_{4} \cdot 10 \mathrm{H}_{2} \mathrm{O}\right)$ and Epsomite $\left(\mathrm{MgSO}_{4} \cdot 12 \mathrm{H}_{2} \mathrm{O}\right)$ is the most common, but also that sodium and potassium nitrate and Halite hydrate $\mathrm{NaCl} \cdot 2 \mathrm{H}_{2} \mathrm{O}$ are formed. The model assumes instantaneous precipitation of these salts and re-equilibration of the solvent. However, the reaction kinetics, especially in a soil matrix with low connectivity of pore spaces, may be slower. This could lead to oversaturation that can cause higher liquid water concentration than the one modeled with FREZCHEM. This tendency seems especially true for samples with high salt concentrations. Another important soil property is the abundance and size of soil pore spaces and small pores on grain surfaces. As stated by Rempel et al. (2001), water surface curvature in small pore spaces can lower freezing points which may be a likely explanation for the deviation between NMR and FREZCHEM modeling that we observed for the samples with low salt concentration. Grain size measurements (Fig. 6) indicate moderate correlations between the grain sizes and difference in the freezing points between NMR and FREZCHEM for small grain sizes. For grain sizes larger than about $200 \mu \mathrm{m}$ no direct correlation is seen; however NMR freezing points are always lower than the ones predicted by FREZCHEM. If pore spaces are smaller and more abundant in soils with small grain sizes, it may provide an explanation for the trend depicted in Fig. 5. Applying a more robust method to analyze pore spaces in soils and on grain surface characteristics may shed more light on the potential influence of pore space on liquid water content in frozen soils.

\section{Conclusion}

Our results indicate that deuteron NMR measurements provide a very precise experimental tool for determination of bulk freezing points as well as the fraction of remaining liquid water when the bulk solvent is frozen. We have observed clear deviations of the experimental freezing points from those modeled solely based on salt composition. In particular, the freezing points determined by NMR show higher liquid water content and lower freezing temperatures for salty soils versus pure solutions. Additionally, there is a lack of clear correlation of the experimental freezing points with the grain sizes. Combined analysis highlights the importance of interfacial interactions at grain/pore surfaces in sustaining liquid water. For very high salt content samples the trend is less clear and this may be due to the slower kinetics of salt precipitation. This study underlines the need of experimental measurements of liquid water content.

\section{Acknowledgements}

This research was supported by CU Denver College of Liberal Arts and Sciences award. NMR and impedance experiments were performed at the National High Magnetic Field Laboratory, which is supported by National Science Foundation Cooperative Agreement No. DMR1157490, the State of Florida and the U.S. Department of Energy. We thanks Dr. Riqiang Fu and Dr. Peter Gor'kov for technical assistance.

\section{Appendix A. Supplementary data}

Supplementary data to this article can be found online at http://dx. doi.org/10.1016/j.geoderma.2017.03.024.

\section{References}

Anderson, R.S., Anderson, S.P., 2010. Geomorphology: The Mechanics and Chemistry of Landscapes. Cambridge University Press.

Anderson, D.M., Morgenstern, N.R., 1973. Physics, chemistry, and mechanics of frozen ground: a review permafrost. Second International Conference. National Academy of Sciences Press, Washington, DC, Yakutsk, U.S.S.R., pp. 257-288.

Anderson, D.M., Tice, A.R., McKim, H.L., 1973. The unfrozen water and the apparent specific heat capacity of frozen soils. Permafrost, Second International Conference. National Academy of Science Press, Washington DC, Yakutsk, U.S.S.R., pp. 289-295

Asay, D.B., Kim, S.H., 2005. Evolution of the adsorbed water layer structure on silicon oxide at room temperature. J. Phys. Chem. B 109, 16760-16763.

Bao, H., Marchant, D.R., 2006. Quantifying sulfate components and their variations in soils of the McMurdo Dry Valleys, Antarctica. J. Geophys. Res. 111, D16301.

Beckmann, P.A., Dybowski, C., 2000. A thermometer for nonspinning solid-state NMR spectroscopy. J. Magn. Reson. 146, 379-380.

Bergknut, M., Laudon, H., Jansson, S., Larsson, A., Gocht, T., Wiberg, K., 2011. Atmospheric deposition, retention, and stream export of dioxins and PCBs in a pristine borea catchment. Environ. Pollut. 159, 1592-1598.

Bockheim, J.G., 2002. Landform and soil development in the McMurdo Dry Valleys, Antarctica: a regional synthesis. Arct. Antarct. Alp. Res. 34, 308-317.

Boxe, C.S., Hand, K.P., Nealson, K.H., Yung, Y.L., Yen, A.S., Saiz-Lopez, A., 2012. Adsorbed water and thin liquid films on Mars. Int. J. Astrobiol. 11, 169-175.

Buehler, M.G., Chin, K.B., Seshadri, S., Keymeulen, D., Anderson, R.C., McCann, T.A., Ieee 2007. Electrical properties probe measures water/ice content of martian soils using impedance spectroscopy. 2007 leee Aerospace Conference. 1-9, pp. 464-482.

Campbell, I.B., Claridge, G.G.C., 1987. Antarctica: Soils, Weathering Processes and Environment. Elsevier, Amsterdam.

Chevrier, V.F., Hanley, J., Altheide, T.S., 2009a. Stability of perchlorate hydrates and their liquid solutions at the Phoenix landing site, Mars. Geophys. Reser. Lett. 36 (6), L10202.

Chevrier, V.F., Ulrich, R., Altheide, T.S., 2009b. Viscosity of liquid ferric sulfate solution and application to the formation of gullies on Mars. J. Geophys. Res. 114, E06001.

Claridge, G.G.C., Campbell, I.B., 1984. Mineral transformation during the weathering of dolerite under cold arid conditions in Antarctica. New Zealand. J. Geol. Geophys. 27 537-545.

Crocker, J.C., Matteo, J.A., Dinsmore, A.D., Yodh, A.G., 1999. Entropic attraction and repulsion in binary colloids probed with a line optical tweezer. Phys. Rev. Lett. 82, 4352-4355.

Cull, S.C., Arvidson, R.E., Catalano, J.G., Ming D.W., Morris, R.V., Mellon, M.T., Lemmon, M. 2010. Concentrated perchlorate at the Mars Phoenix landing site: evidence for thin film liquid water on Mars. Geophys. Res. Lett. 37.

Dash, J.G., Fu, H., Wettlaufer, J.S., 1995. The premelting of ice and its environmental consequences. Rep. Prog. Phys. 58, 115-167.

Davila, A.F., Duport, L.G., Melchiorri, R., Janchen, J., Valea, S., de los Rios, A., Fairen, A.G., Mohlmann, D., McKay, C.P., Ascaso, C., Wierzchos, J., 2010. Hygroscopic salts and the potential for life on Mars. Astrobiology 10, 617-628.

Dickinson, W.W., Rosen, M.R., 2003. Antarctic permafrost: an analogue for water and diagenetic minerals on Mars. Geology 31, 199-202.

Faure, G., Felder, R.P., 1981. Isotope composition of strontium and sulfur in secondary gypsum crystalls, Brown Hills, Transantarctic Mountains. J. Geochem. Explor. 14, 265-270.

Frauenfelder, H., Chen, G., Berendzen, J., Fenimore, P.W., Jansson, H., McMahon, B.H., Stroe, I.R., Swenson, J., Young, R.D., 2009. A unified model of protein dynamics. Proc. Natl. Acad. Sci. U. S. A. 106, 5129-5134.

Geissbuhler, P., Fenter, P., DiMasi, E., Srajer, G., Sorensen, L.B., Sturchio, N.C., 2004. Threedimensional structure of the calcite-water interface by surface X-ray scattering. Surf. Sci. 573, 191-203.

Goertz, M.P., Houston, J.E., Zhu, X.-Y., 2007. Hydrophilicity and the viscosity of interfacial water. Langmuir 23, 5491-5497.

Graziano, G., 2010. On the molecular origin of cold denaturation of globular proteins Phys. Chem. Chem. Phys. 12, 14245-14252.

Hagedorn, B., Sletten, R.S., Hallet, B., 2007. Sublimation and ice condensation in hyperarid soils: modeling results using field data from Victoria Valley, Antarctica. J. Geophys. Res. 112, F03017.

Hagedorn, B., Sletten, R.S., Hallet, B., McTigue, D.F., Steig, E.J., 2010. Ground ice recharge via brine transport in frozen soils of Victoria Valley, Antarctica: insights from modeling $\delta 180$ and $\delta \mathrm{D}$ profiles. Geochim. Cosmochim. Acta 74, 435-448.

Hanley, J., Chevrier, V.F., Berget, D.J., Adams, R.D., 2012. Chlorate salts and solutions on Mars. Geophys. Res. Lett. 39, L08201.

Hecht, M.H., Kounaves, S.P., Quinn, R.C., West, S.J., Young, S.M.M., Ming, D.W., Catling, D.C Clark, B.C. Boynton, W.V., Hoffman, J., DeFlores, L.P., Gospodinova, K., Kapit, J., Smith, P.H., 2009. Detection of perchlorate and the soluble chemistry of Martian soil at the Phoenix lander site. Science 325, 64-67.

Horiguchi, K., 1987. An osmotic model for soil freezing. Cold Reg. Sci. Technol. 14, 13-22.

Israelachvili, J., Wennerstrom, H., 1996. Role of hydration and water structure in biological and colloidal interactions. Nature 379, 219-225.

Jiang, Y.J., 2000. A simple method for measuring the Q value of an NMR sample coil. J. Magn. Reson. 142, 386-388. 
Jones, L.M., Faure, G., 1978. A study of strontium isotopes in lakes and surficial deposits of the ice-free valleys, Southern Victoria Land, Antarctica. Chem. Geol. 22, 107-120.

Karaborni, S., Smit, B., Heidug, W., Urai, J., vanOort, E., 1996. The swelling of clays: molecular simulations of the hydration of montmorillonite. Science 271, 1102-1104.

Keys, J.R.H., Williams, K., 1981. Origin of crystalline, cold desert salts in the McMurdo region, Antarctica. Geochim. Cosmochim. Acta 45, 2299-2309.

Kounaves, S.P., Stroble, S.T., Anderson, R.M., Moore, Q., Catling, D.C., Douglas, S., McKay, C.P., Ming, D.W., Smith, P.H., Tamppari, L.K., Zent, A.P., 2010. Discovery of natural perchlorate in the Antarctic Dry Valleys and its global implications. Environ. Sci. Technol. 44, 2360-2364.

Krushelnitsky, A., Zinkevich, T., Mukhametshina, N., Tarasova, N., Gogolev, Y., Gnezdilov, O., Fedotov, V., Belton, P., Reichert, D., 2009. C-13 and N-15 NMR study of the hydration response of T4 lysozyme and alpha B-Crystallin internal dynamics. J. Phys. Chem. B 113, 10022-10034.

Levy, J.S., Fountain, A.G., Welch, K.A., Lyons, W.B., 2012. Hypersaline wet patches in Taylor Valley, Antarctica. Geophys. Res. Lett. 39, L05402.

Mallamace, F., Chen, S.H., Broccio, M., Corsaro, C., Crupi, V., Majolino, D., Venuti, V., Baglioni, P., Fratini, E., Vannucci, C., Stanley, H.E., 2007. Role of the solvent in the dynamical transitions of proteins: the case of the lysozyme-water system. J. Chem. Phys. 127, 045104.

Marion, G., Farren, 1999. Mineral solubilities in the Na-K-Mg-Ca- $-\mathrm{SO}_{4}-\mathrm{H}_{2} \mathrm{O}$ system: a reevaluation of the sulfate chemistry in Spencer-Moller-Weare model. Geochim. Cosmochim. Acta 63, 1305-1318.

Marion, G.M., 2001. Carbonate mineral solubility at low temperatures in the Na-K-Mg-Ca$\mathrm{H}-\mathrm{Cl}-\mathrm{SO}_{4}-\mathrm{OH}-\mathrm{HCO}_{3}-\mathrm{CO}_{3}-\mathrm{CO}_{2}-\mathrm{H}_{2} \mathrm{O}$ system. Geochim. Cosmochim. Acta 65 1883-1896.

Marion, G.M., 2002. A molal-based model for strong acid chemistry at low temperatures $(<200$ to $298 \mathrm{~K})$. Geochim. Cosmochim. Acta 66, 2499-2516.

Marion, G.M., Grant, S.A., 1994. FREZCHEM: A Chemical-Thermodynamic Model for Aqueous Solutions at Subzero Temperatures. Defense Technical Information Center, Hanover, $\mathrm{NH}$.

Marion, G.M., Kargel, J.S., 2008. Cold Aqueous Planetary Geochemistry With FREZCHEM From Modeling to the Search for Life at the Limits Introduction, Cold Aqueous Planetary Geochemistry With Frezchem: From Modeling to the Search for Life.

Marion, G.M., Catling, D.C., Zahnle, K.J., Claire, M.W., 2010. Modeling aqueous perchlorate chemistries with applications to Mars. Icarus 207, 675-685.

Parkhurst, D.L., Appelo, C.A.J., 1999. PHREEQC (Version2) - a computer program for speciation, batch-reaction, one-dimensional transport and inverse geochemical calculation. Water Resources Investigations. U.S. Department of the Interior, US Geological Survey, Denver.

Poulet, F., Arvidson, R.E., Bibring, J.P., Gondet, B., Jouglet, D., Langevin, Y., Morris, R.V. 2010. Mineralogy of the Phoenix landing site from OMEGA observations and how that relates to in situ Phoenix measurements. Icarus 205, 712-715.

Rempel, A.W., 2011. Microscopic and environmental controls on the spacing and thickness of segregated ice lenses. Quat. Res. 75, 316-324.

Rempel, A.W., Wettlaufer, J.S., Worster, M.G., 2001. Interfacial premelting and the thermomolecular force: thermodynamic buoyancy. Phys. Rev. Lett. 87, 088501.

Rempel, A.W., Wettlaufer, J.S., Worster, M.G., 2004. Premelting dynamics in a continuum model of frost heave. J. Fluid Mech. 498, 227-244.

Rennó, N.O., Bos, B.J., Catling, D., Clark, B.C., Drube, L., Fisher, D., Goetz, W., Hviid, S.F., Keller, H.U., Kok, J.F., Kounaves, S.P., Leer, K., Lemmon, M., Madsen, M.B.
Markiewicz, W.J., Marshall, J., McKay, C., Mehta, M. Smith, M Zorzano, M.P., Smith, P.H., Stoker, C., Young, S.M.M., 2009. Possible physical and thermodynamical evidence for liquid water at the Phoenix landing site. J. Geophys. Res. 114, E00E03.

Seshadri, S., Chin, K.B., Buehler, M.G., Anderson, R.C., 2008. Using electrical impedance spectroscopy to detect water in planetary Regoliths. Astrobiology 8, 781-792.

Skelton, A.A., Fenter, P., Kubicki, J.D., Wesolowski, D.J., Cummings, P.T., 2011. Simulations of the quartz(10(1)over-bar1)/water Interface: a comparison of classical force fields, ab initio molecular dynamics, and X-ray reflectivity experiments. J. Phys. Chem. C 115, 2076-2088.

Sparrman, T., Oquist, M., Klemedtsson, L., Schleucher, J., Nilsson, M., 2004. Quantifying unfrozen water in frozen soil by high-field 2H NMR. Environ.Sci. Technol. 38, $5420-5425$

Sterpone, F., Stirnemann, G., Laage, D., 2012. Magnitude and molecular origin of water slowdown next to a protein. J. Am. Chem. Soc. 134, 4116-4119.

Tice, A.R., 1984. The Effects of Soluble Salts on the Unfrozen Water Contents of the Lanzhou, P.R.C., Silt. U.S. Army Cold Regions Research and Engineering Laboratory, Hanover, N.H.

Toner, J.D., Sletten, R.S., 2013. The formation of ca-cl-rich groundwaters in the dry valleys of Antarctica: field measurements and modeling of reactive transport. Geochim. Cosmochim. Acta 110, 84-105.

Toner, J.D., Sletten, R.S., Prentice, M.L., 2013. Soluble salt accumulations in Taylor Valley, Antarctica: implications for paleolakes and Ross Sea Ice Sheet dynamics. J. Geophys. Res. Earth Surface 118, 198-215.

Tooley, M.H., 2002. Electronic Circuits: Fundamentals and Applications. Taylor \& Francis.

Ugolini, F.C., 1986. Pedogenic zonation in the well-drained soils of the Arctic regions. Quat. Res. 26, 100-120.

Ugolini, F.C., Bockheim, J.G., 2008. Antarctic soils and soil formation in a changing environment: a review. Geoderma 144, 1-8.

Vold, R.L., Vold, R.R., 1991. Deuterium relaxation in molecular solids. In: Warren, W. (Ed.), Advances in Magnetic and Optical Resonance. Acadenic Press, San Diego, pp. 85-171.

Vugmeyster, L., Ostrovsky, D., Ford, J.J., D B., S., Lipton, A.S., Hoatson, G.L., Vold, R.L., 2009. Probing the dynamics of a protein hydrophobic core by deuteron solid-state nuclear magnetic resonance spectroscopy. J. Am. Chem. Soc. 131, 13651-13658.

Vugmeyster, L., Ostrovsky, D., Khadjinova, A., Ellden, J., Hoatson, G.L., Vold, R.L., 2011. Slow motions in the hydrophobic core of chicken villin headpiece subdomain and their contributions to configurational entropy and heat capacity from solid-state deuteron NMR measurements. Biochemistry 50, 10637-10646.

Vugmeyster, L., Do, T., Ostrovsky, D., Fu, R., Hagedorn, B., 2012. Characterization of water dynamics in frozen soils by solid-state deuteron NMR. Solid State Nucl. Magn. Reson. 45-46, 11-15.

Watanabe, K., Wake, T., 2009. Measurement of unfrozen water content and relative permittivity of frozen unsaturated soil using NMR and TDR. Cold Reg. Sci. Technol. 59, $34-41$.

Wilson, A.T., 1979. Geochemical problems of the Antarctic dry areas. Nature 280, 205-208.

Zorzano, M.P., Mateo-Marti, E., Prieto-Ballesteros, O., Osuna, S., Renno, N., 2009. Stability of liquid saline water on present day Mars. Geophys. Res. Lett. 36, L20201. 